\title{
Deriving Key Virtues of Personality Education by Development Stage Using Delphi Survey Method
}

\author{
MyungSun Park1), YoonJoo Lee2)
}

\begin{abstract}
The purpose of this study is to derive core virtues of personality education by the development stage recognized by incumbent teachers through the survey of Delphi experts of incumbent teachers. To this end, a panel of 40 incumbent teachers was formed and surveyed three times from March to August 2018. First, positive thoughts and audits were derived from key virtues of personality education recognized by infant teachers. Second, the key virtues of personality education recognized by elementary school teachers were self-esteem, listening and caring. Third, the core virtues of character education recognized by middle school teachers were empathy and consideration. Fourth, the core virtues of character education recognized by high school teachers were empathy, community consciousness and self-respect. Fifth, when comparing the characteristics of the core virtues of personality education derived from each stage of development, self-esteem was found to be a key virtue that is common in all stages of development. In addition, positive thoughts and self-esteem, which are the sub-core virtues of self-respect, were high for infants and elementary school students, while empathy, the sub-core virtues of self-respect, was high for middle and high school students, and there were a differences in development stages. Therefore, the research is expected to be used as basic data for personality education in the future and to develop personality enhancement programs based on core virtues of personality education at each stage of development. Above all, it will play an important role in shaping students' desirable personality.
\end{abstract}

Keywords: Cardinal Virtues Center Character Through Education, Character Through Education By Developmental Sage, Character Through Education Key Cardinal Virtues, Delphi Enumeration Method, Human Nature

\section{Introduction}

The Greek philosopher Heraclitus said, 'Personality is destiny.' This means that you must have the right character to carve out your destiny in a good way. In addition, the ultimate purpose of all the education our forefathers did to their offspring was to be "right people." Personality

Received(September 30, 2019), Review Result(1st: October 28, 2019, 2nd: December 09, 2019), Accepted(February 20, 2020)

1)(Student, Lead Author) 38541 Dept. pedagogy, Yeungnam Univ., Daehak-ro, Gyeongsan-si, Gyeongsangbuk-do, Korea

email: happypms@hanmail.net

2)(Professor, Corresponding Author) 38541 Dept. pedagogy, Yeungnam Univ., Daehak-ro, Gyeongsan-si, Gyeongsangbuk-do, Korea

email: icu2389@naver.com 
is the state of a person with good manners and values the correct posture or attitude(山, 2011). Park Eui-soo(2009) said that personality education should be aimed at nurturing people who have the right personality through the harmonious development of the "jideok body"[1]. This means that education should include not only knowledge-related cognitive areas but also morality and health. Since ancient times, the nation's Personality education has been primarily conducted by parents and grandparents at home. In other words, some of the personality education at home was called "Rice top education." It was a place where many generations learned manners and consideration by dining together and also by having the ability to communicate with different age groups without difficulty. It provides the opportunity for parents to become the main body and learn the virtues necessary for the family to live in, and taught them to grow into a desirable person with a tributary body (Huh Tae-geun, 2019). However, personality education in the family has become more dysfunctional as our society has gradually become a nuclear family, coupled with the weakening of the education on the head of the table. Even so, personality education at the educational scene has been one of the important goals of school education since the first curriculum. Personality education is becoming more emphasized recently because personality education is being forgotten at the site of school education(Yangjeongsil et, 2013). In other words, personality education was actively pursued from the first curriculum, but there are limits to the practice of personality education at school sites. Thus, the Act on Promotion of Humanity Education, which obligates personality education, took effect in July 2015. The approaches of personality education include a virtues-oriented approach, a cognitive development approach, a consideration-oriented approach, an integrated approach, and a social and emotional approach[1]. Since the 7th curriculum recently, personality education has been trying to take a Virtue-centered approach. Virtue-centered education refers to education that focuses on helping to harmonize and develop the virtues required for Personality education based on the view that personality consists of virtues(Yu Byung-ryul, 2006). This emphasizes the formulation and development of habits for students in schools by specifying the virtues they need to cultivate in forming a good personality(Nuci \& Narvaze, 2008). Therefore, it is most important to clearly establish which virtues you want to cultivate first in moral Personality education[2]. For example, if key virtues such as consideration and responsibility are selected, a program is developed to foster them.

The emphasis on virtues in Personality education stems from Aristotels (1993) We become right by doing the right thing, temperate by doing the right thing, and brave by doing the brave thing(Aristotels, Choi Myung-kwan, 1993) said, virtue is learned by training. Therefore, teaching virtues should be able to determine when and some time to practice them( $\mathrm{Yu}$ 
Byeong-yeol, 2012). In other words, Personality education is about finding and organizing core virtues and teaching them the core virtues necessary in Personality education, which will be meaningful in making the value of core virtues clearer. also in terms of development, Personality changes according to what one human experience has, that values, the direction of life, and the level of moral behavior in terms of quality, If you think about how character formation works through a whole life process, you can see that personality education is an important task throughout the entire life[3]. According to Erikson, humans have the virtue of a desirable personality to develop from birth to death(Hyun Joo, 2009). Lockwood(2009) also strongly argues that students should consider the level of development in Personality education. It was noted that considering the level of development was helpful in the operation of the curriculum and in teaching-learning. First, it helps determine which topics and issues at each grade level are important and unimportant. Second, it lets students know what cognitive abilities they have in each period of the development process. Third, provide directions in predicting students' understanding and attitudes to the moral or other values prevailing at each stage of development. Above all, considering that there is not enough time to cultivate virtues in life, it will be necessary to extract and train the core virtues at each development period. Fortunately, through the enactment of the Personality Education Promotion, for the sake of one's character education in school When the school plan is established every year by the head of the school in the unit school, It was mandatory to organize and operate a school curriculum that fosters core competencies of personality based on core virtues of personality education. This expanded the base for personality education to be planned and operated in accordance with the development stage. In addition, the current Act on the Promotion of Personality Education lists eight core values and virtues for the purpose of Personality education. However, compared to the preceding study of human virtues education, studies in which key virtues are extracted from the various virtues of character and then structured according to the development stage are relatively lacking. Therefore, studies involving more explicit criteria for extracting key virtues at each stage of development are required. teachers' expertise does not simply mean curriculum expertise, but refers to the sum total of their knowledge of subjects, teaching ability to teach them well, student counseling and guidance ability, class management ability, educational insight, values, attitudes, and self-development as lifelong learners(Baek In Sun, 2011). In other words, teachers already include Personality education in the meaning and role of teachers, and are the key players in Personality education. Therefore, the perception of incumbent teachers will be most appropriate in extracting the core virtues of Personality education. If we look at domestic studies so far, it has been difficult to find a study to extract 
key virtues from experts in education sites. This research was conducted through a Delphi survey of incumbent teachers who are experts on educational sites in orders to derive the core virtues of Personality education in each stage of development. The Delphi survey can lead to agreed opinions from the group without having to gather and debate directly by experts who participated in the survey(Park Sang-seop, 2013) through the repeat and feedback of a carefully planned survey to allow the expert group to exchange various information and opinions. In this study, the Delphi survey aims to classify the core virtues of Personality education recognized by incumbent teachers by development stage and find out what the core virtues required by the development stage.

The study questions set in accordance with the aforementioned research objectives are as follows.

Study 1 . What are the key virtues of childhood personality education recognized by infant teachers?

Study 2. What are the key virtues of children's desirable Personality education recognized by elementary school teachers?

Study 3. What are the key virtues of middle school students' desirable Personality education recognized by middle school teachers?

Study 4. What are the key virtues of high school students' desirable personality education recognized by high school teachers?

Study 5. What are the Personalityistics of the core virtues of personality education at each stage of development?

\section{Research Method}

\subsection{Open Survey for Delphi Survey}

In this study, the core virtues of personality education were derived by using open survey tools for incumbent teachers in infants, elementary, middle and high schools. The open survey tools aimed at drafting core virtues in personality education for each stage of development. The open survey tools used to do this provided a blank space for unlimited listing of the virtues that they thought were, and also allowed them to express their views on their ideas or beliefs about the virtues mentioned. The composition of the questionnaire is consisted of one question of personality virtues required by students, one question of reason why the mentioned character virtues were deemed necessary in consideration of the development stage, and one 
question of difficulty encountered in providing Personality education on the site. Open survey targets was a total of 264 incumbent teachers Infants (71 children), elementary school (71 students), middle school (67 students), and high school (55 students), The period was conducted from March to July 2018. Open survey methods were asked to list their thoughts unlimitedly in the manner of e-mail, Google, SNS and individual interviews. All of the data collected were classified and nomadic by development stage through Excel and extracted the core virtues of Personality education.

\subsection{Delphi Research}

\subsubsection{Subject to Study}

A group of experts targets the Delphi survey method. Selection criteria are set to improve the reliability of panel selection. In this study, the panel of experts was staffed with teachers and principals with more than 10 years of experience. The Delphi survey panel targeted teachers because they are in the best position to do personality education at school sites. For the construction of Delphi survey panels, 40 people were invited from March to August 2018 for each of the incumbent working-level officials, who guided the research purpose, content and procedures through telephone, email or visit, and then appointed them to the expert panel with consent to participate. According to the results of the Delphi survey, kindergarten is 9 women and 1 man, career 11year is 1person, 12years is 4person, 14years is 1person, 17years is 1person, 18years is 2person, 32years is 1person. According to the results of the Delphi survey, elementary schools is 7women and 3man, career 11years is 1person, 12years is 1person, 17years is 1person, 18years is 2person, 19years is 1person, 23years is 1person, 25years is 1 person, 32years is 1person, 37years is 1person. also According to the results of the Delphi survey, middle schools is 6women and 4man, career 11years is 3person, 12years is 1person, 14years is 1person, 21years is 1person, 24years is 1person, 27years is 1person, 30years is 2person. According to the results of the Delphi survey, high school is 5women and 5man, career 12years, 15years, 17years, 19years, 23years, 24years, 27years, 28years, 30years, 37years one each. The criteria for selecting the Delphi survey experts panel and the number of participants in this study are As shown in [Table 1]. 
[Table 1] Selection Criteria for Delphi Survey Panels and Number of Participants

\begin{tabular}{|c|c|c|c|c|}
\hline \multirow[b]{2}{*}{ Classification } & \multirow[b]{2}{*}{$\begin{array}{l}\text { The initial number of } \\
\text { personnel }\end{array}$} & \multicolumn{3}{|c|}{ Participation personnel } \\
\hline & & $\begin{array}{l}\text { The } \\
\text { first }\end{array}$ & $\begin{array}{l}\text { Secon } \\
\text { dary }\end{array}$ & $\begin{array}{l}\text { Terti } \\
\text { ary }\end{array}$ \\
\hline $\begin{array}{l}\text { Daycare centers with more than } 10 \text { years of } \\
\text { experience a kindergarten principal }\end{array}$ & 10 & 10 & 10 & 10 \\
\hline $\begin{array}{l}\text { Incumbent teachers and principals of elementary } \\
\text { schools with more than } 10 \text { years of experience }\end{array}$ & 10 & 10 & 10 & 10 \\
\hline $\begin{array}{l}\text { Present teachers and principals of middle schools } \\
\text { with more than } 10 \text { years of experience }\end{array}$ & 10 & 10 & 10 & 10 \\
\hline $\begin{array}{l}\text { High school incumbent and high school with more } \\
\text { than } 10 \text { years of experience }\end{array}$ & 10 & 10 & 10 & 10 \\
\hline Total & 40 & 40 & 40 & 40 \\
\hline
\end{tabular}

\subsubsection{Data Collection}

\subsubsection{The First Delphi Survey}

The first Delphi survey was aimed at developing the second Delphi survey tool to reflect experts' opinions on the major virtues derived from the public survey. The tool used in the first Delphi survey was a public survey. The method of investigation was to provide Delphi experts with definitions of key virtues derived from public surveys using the National Korean Language Institute and the Korean language dictionary, select five key virtues required for the development stage by grade, and write down the reasons and circumstances. The results of the first Delphi survey were derived by classifying and integrating core virtues in overlapping or similar meanings among experts.

\subsubsection{The Secondary Delphi Survey}

The second Delphi survey was aimed at gathering opinions from Delphi experts on the results of the first Delphi survey. To this end, the results of the first Delphi survey were analyzed and the second Delphi questionnaire was organized. The second Delphi questionnaire form required the importance of the derived core virtues to be leveled on a 5-point Likert scale, and at the end of each question, the frequency and percentage of responses of each virtue were presented to participate in the decision making. The results of the second Delphi survey analyzed the response results of expert panels and calculated the average by item.

\subsubsection{The Tertiary Delphi Survey}

The Tertiary Delphi survey was aimed at making a final agreement to reflect the second 
opinion of Delphi experts. The Tertiary Delphi survey tool was almost identical to the Secondary survey, but the results of the response from the Secondary were calculated and presented with a median, average, and ranking of the results. The results of the Tertiary Delphi survey analyzed the results of the responses of expert panels and calculated the mean and standard deviation of each item. The consensus and convergence of opinions were verified by analyzing the validity of the opinions presented by expert panels.

\subsubsection{Data Analysis}

Open questionnaire responses, Delphi responses, and reliability surveys were statistical under the Excel and SPSS 22.0 programs, and teachers' group survey results and Delphi statistics were analyzed and handled independently by class, respectively. The Tertiary Delphi survey analysis validated the consensus and convergence by analyzing the validity of the opinions presented by expert panels. The results of the survey determined that If the consensus is more than .75 and the convergence is between 0 and 5 , the panelists' opinions were judged to have been reached and expressed in thickly. In addition, Personality education can be used as a method of moral education that presents a list of virtues (Carr, 1991) adopted a view and made it a basis for the analysis of this study. Accordingly, the core virtues of Personality education were divided and analyzed for each stage of development. The virtues used in this study are that by reference of the research by Heo Kyung-chul and Cho Nan-sim (1994) and Park Mi-Hwa (1998) was rewritten by this researcher.

\section{Research Result}

\subsection{Main Virtues of Personality Education for Infants}

In the first Delphi survey, positive thoughts and considerations were high, while in the second Delphi survey, positive thoughts and gratitude were higher than the first Delphi survey, and consideration and creativity were low. In addition, the third Delphi survey showed that positive thinking was the highest, and that the second Delphi survey showed a low emotional stability. In addition, when compared to the criteria rewritten by this researcher, the core virtues were derived in the orders of self-respect and democratic citizenship. A summary of the results of the third survey on the key virtues of personality education required for infants is shown in [Table 2] below. 
Deriving Key Virtues of Personality Education by Development Stage Using Delphi Survey Method

[Table 2] A Third Survey on the Core Virtues of Personality Education for Infants

\begin{tabular}{|c|c|c|c|c|c|}
\hline \multirow{2}{*}{ Sortation } & \multicolumn{5}{|c|}{ Kindergarten } \\
\cline { 2 - 6 } & Virtuous & Average & $\begin{array}{c}\text { standard } \\
\text { deviation }\end{array}$ & convergence & Agreement \\
\hline Self-respect & positive thinking & 4.90 & 0.32 & 0.50 & 1.00 \\
\hline other people's respect & Thanks & 4.80 & 0.42 & 0.53 & 0.95 \\
\hline other people's respect & Love & 4.70 & 0.67 & 0.53 & 0.95 \\
\hline Self-respect & Confidence & 4.70 & 0.48 & 0.63 & 0.80 \\
\hline Self-respect & Self-esteem & 4.60 & 0.70 & 0.63 & 0.80 \\
\hline Self-respect & A habit of living & 4.50 & 0.71 & 0.63 & 0.80 \\
\hline other people's respect & Respect & 4.50 & 0.71 & 0.63 & 0.80 \\
\hline other people's respect & Listening attentively & 4.20 & 0.63 & 0.67 & 0.69 \\
\hline democratic citizen & Compliance with & 4.20 & 0.79 & 0.63 & 0.75 \\
\hline Self-respect & Emotional stability & 4.20 & 0.79 & 0.67 & 0.69 \\
\hline democratic citizen & Cooperation & 4.10 & 0.74 & 0.67 & 0.69 \\
\hline other people's respect & Sharing & 4.00 & 0.67 & 0.57 & 0.88 \\
\hline other people's respect & Manners & 4.00 & 0.67 & 0.57 & 0.88 \\
\hline
\end{tabular}

\subsection{Main Virtues of Personality Education for Elementary School Students}

The first Delphi survey showed high listening, consideration and cooperation, while the second Delphi survey showed lower cooperation than the first Delphi survey and higher happiness pursuit, affirmation and community consciousness. Also, the third Delphi survey showed the highest level of self-esteem and the low level of practice and love shown in the second Delphi survey. Also, if you compare it to the criteria rewritten by this researcher, Sub-core virtues of self-respect are most often derived, Next, the core virtues were derived in the orders of democratic civic consciousness and respect for others. The results of the third survey on the core virtues of Personality education for elementary school students are summarized in Table 3 below.

[Table 3] A Third Survey on the Core Virtues of Personality Education for Elementary School Students

\begin{tabular}{|c|c|c|c|c|c|}
\hline \multirow{2}{*}{ Sortation } & \multicolumn{5}{|c|}{ Elementary School } \\
\cline { 2 - 6 } & Virtuous & Average & $\begin{array}{c}\text { standard } \\
\text { deviation }\end{array}$ & $\begin{array}{c}\text { conver } \\
\text { gence }\end{array}$ & Agreement \\
\hline Self-respect & Self-esteem & 4.70 & 0.48 & 0.50 & 0.80 \\
\hline Other people's respect & Listening attentively & 4.60 & 0.70 & 0.50 & 0.80 \\
\hline Other people's respect & Consideration & 4.60 & 0.97 & 0.13 & 0.95 \\
\hline Self-respect & Positive & 4.50 & 0.97 & 0.50 & 0.80 \\
\hline Other people's respect & Communication & 4.50 & 0.53 & 0.50 & 0.78 \\
\hline Self-respect & pursuit of happiness & 4.50 & 0.71 & 0.50 & 0.80 \\
\hline
\end{tabular}




\begin{tabular}{|c|c|c|c|c|c|}
\hline Democratic citizen & Community spirit & 4.40 & 0.84 & 0.63 & 0.75 \\
\hline Other people's respect & Love & 4.40 & 0.70 & 0.50 & 0.78 \\
\hline Democratic citizen & Practice & 4.40 & 0.52 & 0.50 & 0.75 \\
\hline Democratic citizen & To live together & 4.30 & 0.95 & 0.50 & 0.78 \\
\hline Democratic citizen & Responsibility & 4.20 & 0.92 & 0.50 & 0.75 \\
\hline Democratic citizen & Cooperation & 4.20 & 0.63 & 0.50 & 0.75 \\
\hline Self-respect & Challenge Consciousness & 4.10 & 0.57 & 0.13 & 0.94 \\
\hline Self-respect & Diligence & 4.10 & 0.57 & 0.13 & 0.94 \\
\hline Democratic citizen & Matching & 4.10 & 0.32 & 0.00 & 1.00 \\
\hline Self-respect & Self-understanding & 4.10 & 0.88 & 1.00 & 0.50 \\
\hline Self-respect & Own'right pursuit of happiness & 4.10 & 0.74 & 0.63 & 0.69 \\
\hline Other people's respect & Honesty & 4.10 & 0.88 & 0.50 & 0.75 \\
\hline Self-respect & Creativity & 4.10 & 0.88 & 1.00 & 0.50 \\
\hline Democratic citizen & Compliance with rules & 4.00 & 1.05 & 1.00 & 0.50 \\
\hline Self-respect & Habit of living & 4.00 & 0.82 & 0.13 & 0.94 \\
\hline Democratic citizen & Citizenship & 4.00 & 0.94 & 0.63 & 0.69 \\
\hline Other people's respect & Manners & 4.00 & 0.82 & 0.13 & 0.94 \\
\hline Self-respect & Self-control & 4.00 & 0.82 & 0.13 & 0.94 \\
\hline
\end{tabular}

\subsection{Main Virtues of Personality Education for Middle School Students}

The first Delphi survey showed high empathy, consideration and self-esteem. The second Delphi survey also showed the highest level of empathy and consideration, the first Delphi survey was so low the communal consciousness but It's been shown high, and then was communication shown high, but autonomy was very low. The third Delphi survey also showed the highest empathy, the lowest emotional stability in the second Delphi survey, and increased mutual respect and responsibility. In addition, when compared to the criteria rewritten by this researcher, the core virtues were derived in the orders of self-respect and democratic citizenship. The key attributes of Personality education for middle school students are summarized in Table 4 below.

[Table 4] A Third Survey on the Core Virtues of Personality Education for Middle School Students

\begin{tabular}{|c|c|c|c|c|c|}
\hline \multirow{2}{*}{ Sortation } & \multicolumn{5}{|c|}{ Middle School } \\
\cline { 2 - 6 } & Virtuous & Average & $\begin{array}{c}\text { standard } \\
\text { deviation }\end{array}$ & convergence & Agreement \\
\hline Other people's respect & Empathy & 4.90 & 0.32 & 0.00 & 1.00 \\
\hline Other people's respect & Consideration & 4.80 & 0.42 & 0.13 & 0.95 \\
\hline Other people's respect & Mutual respect & 4.70 & 0.48 & 0.50 & 0.80 \\
\hline Self-respect & Self-esteem & 4.70 & 0.48 & 0.50 & 0.80 \\
\hline Democratic citizen & Responsibility & 4.70 & 0.48 & 0.50 & 0.80 \\
\hline Other people's respect & Thanks & 4.50 & 0.71 & 0.50 & 0.80 \\
\hline Democratic citizen & To live together & 4.50 & 0.71 & 0.50 & 0.80 \\
\hline
\end{tabular}


Deriving Key Virtues of Personality Education by Development Stage Using Delphi Survey Method

\begin{tabular}{|c|c|c|c|c|c|}
\hline Other people's respect & Use the correct language & 4.30 & 0.67 & 0.50 & 0.75 \\
\hline Democratic citizen & Community spirit & 4.20 & 0.79 & 0.63 & 0.69 \\
\hline Other people's respect & Communication & 4.20 & 0.63 & 0.50 & 0.75 \\
\hline Self-respect & Emotional stability & 4.20 & 0.63 & 0.50 & 0.75 \\
\hline Self-respect & Habit of living & 4.10 & 0.74 & 0.63 & 0.69 \\
\hline Other people's respect & Altruism & 4.10 & 0.74 & 0.63 & 0.69 \\
\hline Self-respect & Self-control & 4.00 & 0.82 & 1.00 & 0.50 \\
\hline
\end{tabular}

\subsection{Main Virtues of Personality Education for High School Students}

The first Delphi survey showed high empathy, while the second Delphi survey showed the highest sense of community, which was low in the first Delphi survey. And while the first Delphi survey showed a low level of self-respect, self-esteem and living together, it showed lower humility, tolerance and value. Also, the third Delphi survey showed the highest sympathy. Compliance and orders were higher than the second Delphi survey, while self-searching, which was higher in the second Delphi survey, was the lowest, and the right lifestyle and language habits were also the lowest. In addition, the sub-core virtues of self-respect were derived most when compared to the criteria rewritten by this researcher, followed by those of others and democratic citizens. A summary of the key attributes of Personality education for high school students is shown in Table 5 below.

[Table 5] A third Survey on the Core Virtues of Personality Education for High School Students

\begin{tabular}{|c|c|c|c|c|c|}
\hline \multirow{2}{*}{ Sortation } & \multicolumn{5}{|c|}{ High School } \\
\cline { 2 - 6 } & Virtuous & Average & $\begin{array}{c}\text { standard } \\
\text { deviation }\end{array}$ & convergence & Agreement \\
\hline Other people's respect & Empathy & 4.60 & 0.84 & 0.25 & 0.90 \\
\hline Democratic citizen & Community spirit & 4.40 & 0.70 & 0.50 & 0.78 \\
\hline Self-respect & Self-respect & 4.40 & 0.84 & 0.63 & 0.75 \\
\hline Self-respect & Effort & 4.30 & 0.67 & 0.50 & 0.75 \\
\hline Self-respect & Self-esteem & 4.30 & 0.67 & 0.50 & 0.75 \\
\hline Democratic citizen & To live together & 4.20 & 0.63 & 0.50 & 0.75 \\
\hline Oher people's respect & Manners & 4.20 & 0.42 & 0.13 & 0.94 \\
\hline Democratic citizen & Love of humanity & 4.20 & 0.79 & 0.63 & 0.69 \\
\hline Other people's respect & Mutual respect & 4.10 & 0.32 & 0.00 & 1.00 \\
\hline Other people's respect & Interact & 4.10 & 1.29 & 0.63 & 0.72 \\
\hline Self-respect & Self-management & 4.10 & 0.74 & 0.63 & 0.69 \\
\hline Self-respect & Self-control & 4.10 & 0.57 & 0.13 & 0.94 \\
\hline Self-respect & Positive thinking & 4.00 & 0.94 & 0.63 & 0.69 \\
\hline Self-respect & Sense of self-efficiency & 4.00 & 0.82 & 1.00 & 0.50 \\
\hline Other people's respect & Respect & 4.00 & 0.47 & 0.00 & 1.00 \\
\hline Democratic citizen & Law of compliance & 4.00 & 0.67 & 0.25 & 0.88 \\
\hline Democratic citizen & Orders & 4.00 & 0.82 & 1.00 & 0.50 \\
\hline
\end{tabular}




\subsection{A Comparative Analysis on the Characteristics of Humanity Education in each} Development Stage

Comparing the core virtues of personality education recognized by incumbent teachers at each stage of development, more were found to be necessary for elementary school students. In terms of core virtues, their self-esteem was high among infants, elementary school students, middle school students and high school students. Also, if you compare it to the criteria that the researcher rewritten, elementary and high school students many of the sub-core virtues of self-respecting consciousness have been derived, infants and middle school students many of the sub-core virtues of other people's respect consciousness have been derived. On the other hand, infants was many of the sub-core virtues of other people's respect consciousness have been derived but in the lower core virtues of self-respect consciousness positive thoughts were high. high school students many of the sub-core virtues of self-respecting consciousness have been derived but Empathy was a sub-core virtue of other people's respect for others was the highest. The results of a detailed analysis of the results of a survey of the key virtues of Personality education required for each stage of development are as shown in Table 6 below.

[Table 6] Comparing the Results of the Survey on the Core Virtues of Personality Education Required by Each Stage of Development

\begin{tabular}{|c|c|c|c|c|c|c|c|c|}
\hline \multirow[b]{2}{*}{$\begin{array}{l}\text { Sor } \\
\text { tati } \\
\text { on }\end{array}$} & \multicolumn{2}{|c|}{ Kindergarten } & \multicolumn{2}{|l|}{ Elementary School } & \multicolumn{2}{|l|}{ Middle School } & \multicolumn{2}{|c|}{ High School } \\
\hline & Virtuous & $\begin{array}{l}\mathrm{Av} \\
\text { era } \\
\text { ge }\end{array}$ & Virtuous & $\begin{array}{l}\text { Av } \\
\text { era } \\
\text { ge }\end{array}$ & Virtuous & $\begin{array}{l}\text { Av } \\
\text { era } \\
\text { ge }\end{array}$ & Virtuous & $\begin{array}{l}\text { Av } \\
\text { era } \\
\text { ge }\end{array}$ \\
\hline \multirow{10}{*}{$\begin{array}{l}\text { Self } \\
\text {-res } \\
\text { pec } \\
t\end{array}$} & $\begin{array}{l}\text { positive } \\
\text { thinking }\end{array}$ & 4.9 & Self-esteem & 4.7 & Self-esteem & 4.7 & Self-respect & 4.4 \\
\hline & Confidence & 4.7 & Positive & 4.5 & Emotional stability & 4.2 & Effort & 4.3 \\
\hline & Self-esteem & 4.6 & pursuit of happiness & 4.5 & Habit of living & 4.1 & Self-esteem & 4.3 \\
\hline & habit of living & 4.5 & $\begin{array}{l}\text { Challenge } \\
\text { Consciousness }\end{array}$ & 4.1 & Self-control & 4.0 & $\begin{array}{l}\text { Love of } \\
\text { humanity }\end{array}$ & 4.2 \\
\hline & $\begin{array}{l}\text { emotional } \\
\text { stability }\end{array}$ & 4.2 & Diligence & 4.1 & & & $\begin{array}{l}\text { Self-manage } \\
\text { ment }\end{array}$ & 4.1 \\
\hline & & & Self-understanding & 4.1 & & & Self-control & 4.1 \\
\hline & & & $\begin{array}{l}\text { Own'right pursuit } \\
\text { of happiness }\end{array}$ & 4.1 & & & $\begin{array}{l}\text { Positive } \\
\text { thinking }\end{array}$ & 4.0 \\
\hline & & & Creativity & 4.1 & & & $\begin{array}{c}\text { Sense of } \\
\text { Self-efficiency }\end{array}$ & 4.0 \\
\hline & & & Habit of living & 4.0 & & & & \\
\hline & & & Self-control & 4.0 & & & & \\
\hline oth & thanks & 4.8 & Listening attentively & 4.6 & Empathy & 4.9 & Empathy & 4.6 \\
\hline er & love & 4.7 & Consideration & 4.6 & Consideration & 4.8 & Manners & 4.2 \\
\hline
\end{tabular}




\begin{tabular}{|c|c|c|c|c|c|c|c|c|}
\hline \multirow{5}{*}{$\begin{array}{c}\text { peo } \\
\text { ple }^{\prime} \\
\text { s } \\
\text { res } \\
\text { pec } \\
t\end{array}$} & Respect & 4.5 & Communication & 4.5 & Mutual respect & 4.7 & Mutual & 4.1 \\
\hline & $\begin{array}{l}\text { listening } \\
\text { attentively }\end{array}$ & 4.2 & Love & 4.4 & Thanks & 4.5 & Interact & 4.1 \\
\hline & Sharing & 4.0 & Honesty & 4.1 & $\begin{array}{c}\text { Use the correct } \\
\text { language }\end{array}$ & 4.3 & Respect & 4.0 \\
\hline & manners & 4.0 & Manners & 4.0 & Communication & 4.2 & & \\
\hline & & & & & Altruism & 4.1 & & \\
\hline \multirow{8}{*}{$\begin{array}{c}\text { de } \\
\text { mo } \\
\text { crat } \\
\text { ic } \\
\text { citi } \\
\text { zen }\end{array}$} & $\begin{array}{l}\text { compliance } \\
\text { with rules }\end{array}$ & 4.2 & Community spirit & 4.4 & Responsibility & 4.7 & $\begin{array}{c}\text { Community } \\
\text { spirit }\end{array}$ & 4.4 \\
\hline & cooperation & 4.1 & Practice & 4.4 & To live together & 4.5 & To live & 4.2 \\
\hline & & & Living together & 4.3 & Community spirit & 4.2 & $\begin{array}{c}\text { Law of } \\
\text { compliance }\end{array}$ & 4.0 \\
\hline & & & Responsibility & 4.2 & & & Orders & 4.0 \\
\hline & & & Cooperation & 4.2 & & & & \\
\hline & & & Matching & 4.1 & & & & \\
\hline & & & $\begin{array}{l}\text { Compliance with } \\
\text { rules }\end{array}$ & 4.0 & & & & \\
\hline & & & Citizenship & 4.0 & & & & \\
\hline
\end{tabular}

\section{Discussion and Conclusion}

The purpose of this study was to derive the core virtues of Personality education for each the developmental stage recognized by an incumbent teacher. The main results of this study are discussed in relation to the preceding study.

First, infants' teachers perceive positive thinking and gratitude as relatively more important as key virtues, it showed. Given the study by Seligman(2004) and Cho Yoo-jin(2015), who stressed that positive emotions such as positive thinking and gratitude in infants sense of happiness be enhanced, positive thinking and sentiment in infants can be seen as important virtues in happiness and social life adaptation. In addition, studies by Kostelnik, Whiren, Soderman, Stein, and \& Gregory(2015) argued that childhood social experience is the basis for all future relationships, meaning that it affects the social relationships experienced in infancy and growing emotions and has a great meaning in life. Scholars emphasize that childhood is an appropriate time to develop audit sentiment through audit training[4]. Emmons \& Shelton(2002) also said that audit tendencies are a virtue that can be developed by an acquired effort, and can be developed through the support and encouragement of adults and through proper education. This can be seen as a way to show how the importance of positive thinking and sentiment in infancy can be learned in the educational scene. Adults with infants need to 
provide educational scenes that encourage and guide infants to have a grateful heart, express gratitude, and form good relationships through positive interactions they can have through gratitude. However, research on positive thinking and auditing derived from the core virtues of infants is very insufficient and further research is needed.

Second, elementary school teachers perceive self-esteem, consideration and communication as relatively more important as key virtues, the report showed. These results are consistent with Kang Kyung-young's(2017) recent study that emphasizes and practices the virtues of consideration, communication and respect over example, filial piety, and honesty. And the key element of character is self-esteem(Jung Jong-jin, 2016), which is one of the tasks of development, Consideration is the basis for achieving amicable social skills, and it is especially when considering the importance of learning in elementary school[5] One can once again confirm that self-esteem and consideration are important key virtues that are emphasized in elementary school. For example, teachers recognized consideration as an important key virtue, such as Yoo Sun-hee, 2016; Min Tae-ok, 2004; Lee Yeon-soo, 2011 by leading researchers who said that caring children would consider others, that they could be good at relationships, that they could have positive effects on peer groups, and that they could be good at interpersonal relationships. The ability to consider others in elementary school is an important developmental task for future social life. In addition, it was seen as a critical period for elementary school students to recognize themselves and others and develop self-concepts in the development stage of Erikson. They also said that children with high self-esteem have a good two-way communication ability to understand other people's thoughts and feelings[5]. However, since elementary school students are beginning to evaluate themselves negatively due to social comparisons and negative feedback from outside(Robins \& Trzesviewsky, 2005), I think there is a great need for a classroom atmosphere to allow students to make mistakes during this period when they acquire the virtues of self-esteem and consent. It is very important that teachers respect and accept their ideas or opinions as an receptive attitude to students(Lee Myung-sook et al, 2011). Moreover, since the social support of teachers and friends is very relevant to self-esteem(An Seol-ha, Moon Hyuk-jun, 2011), if there is an educational environment in which teachers and friends can show their social support in an receptive manner to students, students who grow up in it will have a positive effect of treating themselves and others positively, being more responsible, and being cooperative. Given the impact of self-esteem and consideration on human development, students' self-esteem and self-esteem are important virtues in personality education for healthy self-development, amicable human relationships and interactive communication skills. 
Third, middle school teachers recognized the importance of empathy, consideration and responsibility as the core virtues. In the feudal era, loyalty, filial piety, and example were important virtues[6], but the responsibilities and consideration that democratic citizens and world citizens should have are now being paid attention to as important virtues. This seems to be a characteristic of adolescence, where empathy and consideration derived from core virtues diverge from self-centeredness and focus on the impact of one's actions on relationships with others. Middle school students are still growing emotionally in the developmental stage, and if they miss this period, the empathy education is less effective(Moon Yong-rin, 2011). In addition, given the important time(Kim Kwang-woong, 2005) to lay the foundation for social skills development while experiencing intimacy in relations with others, the education of empathy and consideration for middle school students can be timely and effective in the development stage. Yang Mi-jin, Kim Eun-young and Lee Sang-hee(2008) said empathy is an important indicator as well as a major component of consideration. Choi Yong-sung(2003) also said empathy is the root of caring, loving and altruistic behavior called moral feelings or activities[7]. Given the importance of empathy for improving consideration, the ability to balance the interests of individuals and society and the willingness to guess what ripple effects my actions will have on others can be very important in terms of education. However, the need and importance of consideration are highlighted in the preceding study(Moon Yong-rin, 2011; Choi Yong-sung, 2003), which lacks research related to consideration through empathy. While deriving key virtues from middle schools is useful data by creating Personality education programs, further studies on the relevance between key virtues are also likely to be needed.

Fourth, high school teachers recognized the importance of empathy, community consciousness and self-respect as the core virtues, and they agreed that it was to foster social skills. Given that personality education should be dealt with in the civil education level of Kim Soo-jin(2015) and that thinking about how to live with Lee Yeon-soo(2016)[8] is at the core of personality, the virtues to be acquired in high schools before adulthood can be seen as preparation for becoming a member of a community. A teenager's sense of community is an important variable that can solve the exclusive problem of self-centeredness that is prevalent in our society at present, and serves as an important facilitator in caring and accommodating others[9]. This shows that in a climate of increasing individualism and apathy, community consciousness gives rise to a climate of empathy, cooperation and consideration among members, thus providing an opportunity to unite with emotional bonds within the community. In addition, community consciousness has positive effects on school adaptation, pro-social behavior, and further helps resolve school conflicts and solve problems (Song Jin-young and Choi Young-ran, 
2016), and as youth sense of community increases, life satisfaction and school life adaptation increases (Choi Hyung-e et al, 2013). Therefore, personality education is desperately needed to improve community consciousness and empathy, considering the unique characteristics of teenagers and their timing development. The correct Personality education will be an important means for members of civil society as well as the youth to establish self-identity, form a positive interpersonal relationship, empathy for various values and grow into a social person with a healthy personality. In addition, given the study by Um Sang-hyun(2018), which states that identity is a key factor in character and that self-respecting education should be conducted to foster youth personality, effective personality education requires a way to pay attention to virtues such as self-respect and enhance positive value judgment on self. Combining these ideals, it will be necessary for high school students to engage themselves in activities that encourage solidarity and solidarity in their school life, and to operate clubs.

Fifth, we want to compare the characteristics of the core virtues of Personality education in each stage of development.

First of all, teachers commonly recognized the lower core virtues of self-respect as relatively important at all stages of development, especially self-esteem as the most important core virtues. This is in line with a study by Jeong Jong-jin(2016) that promoting students' self-esteem is an important aspect of personality development. In other words, a self-respecting student has the characteristics of being positive about himself, perceiving himself worthy, and acting with confidence in anything. This positive self-esteem formation of students has been reported to have a significant impact on students' psychological and emotional levels through various prior studies, and so much so that students' self-esteem development is critical[10]. Therefore, Personality education for self-esteem needs to be implemented continuously at each stage of development.

At the same time, we need to take a closer look that Self-control core virtues of self-respecting consciousness was The higher the level of school, they have risen in common

This can be seen as an important virtue of continuing and developing throughout life, given Berk (2006), whose self-control is formed from early childhood to early childhood, and progressively developed from early childhood to early childhood and adolescence. These self-controlled virtues are reported to be increasingly important in this study, as shown by the fact that early in life self-control is an important predictor of healthy, successful lives in later childhood, adolescence and adulthood (Shaffer, 1999). In other words, self-control is a virtue that is directly needed in real adolescence and adulthood, but it can be seen that it must be learned and trained from an early age. Low self-control levels often cause emotional ups and 
downs, lack of attention, and lack of adherence to social norms (Min Soo-hong, 2005), A study of post-adult issues found in the study showed that if you grow up without dealing with the problem behavior, it will lead to various problems (Jwa Hyun-Suk, 2017). In orders to foster self-control, personality education is needed to train behavior or emotional expression in infancy and childhood, habits of setting and achieving goals and attitudes of compliance. However, not only is there a lack of detailed research on the development of self-control, but there is also a lack of program development to improve control. Self-control can be seen as a virtue that needs to be studied as soon as possible, given the recent reports of a number of events related to regulation.

Teachers, on the other hand, did not recognize that the filial piety specified in the Act on the Promotion of Personality Education was important at all stages of development, and were related to the study by Lee Mi-ran(2014) that the virtues were less composed of filial virtues in Personality education. This aspect seems to reflect concerns over the appearance of filial piety, which values too much relationship between the top and the bottom, given a study by Cho Eun-sang(2009), who said traditional filial piety is excessively undemocratic and authoritarian. The authoritative nature of which filial piety can be misrepresented can be a tool for forcing unconditional obedience to the older generation and can hardly help resolve conflicts between generations. Because today's society is based on the equality of democracy and individual respect, vertical and authoritative forms of virtues are even more unacceptable. However, filial piety is filial piety to parents, brotherly friendship, neighborly adults and siblings like my parents and brothers, and furthermore, consideration and respect for others. Therefore, in view of these characteristics, filial piety will first have to be harmonized with the values of modern and traditional traditions in orders to melt Personality education at school sites, and modern and democratic reinterpretations, not traditional methods.

Other differences in the developmental stages include: Teachers in infants and elementary schools recognized positive thoughts and self-esteem as the core virtues of self-respect, and middle and high school teachers recognized empathy as relatively important. This is related to the study of Gestwicki(2008) who sees the right time to build a desirable personality and internalize it as an appropriate time for children and elementary school students, and the ability to cooperate with others and to provide interpersonal skills as key capabilities in personality education. In this development phase, childhood can be seen as fostering a balanced core virtue by understanding and embracing oneself positively and forming a positive self-concept, and by embracing others in the future adolescence.

When looking at the key virtues recognized by teachers at each stage of development, the 

key virtues of using the right language appeared only to middle school students. This is related to the study in which Yang Myung-hee(2010) found that the reason for using abusive language has become a habit $(29.4 \%$ of middle school students) and that middle school students are exposed to the Internet or smart devices, and students have high frequency of communication in cyberspace, and the study has shown that the suicide of a famous singer has caused a social concern about malicious comments. Therefore, it is necessary to teach middle school students to use positive language in orders to improve their indiscreet and wrong language habits, build healthy living habits by using the right language, train them in the correct Korean language, and understand the exact meaning of swearwords. And contrary to expectations that the law-abiding spirit would be an important personality education for students, teachers did not recognize it as important, and the law was the only weak showing for high school students. This is in part in the study by Yoon Seong-hak(1996), who said the law duty is not only weak for teenagers but will not be able to function properly. Also, a study (Kim Young-ha, 2005) found that teachers do not affect students' law-abiding spirit is related to this study. This seems to reflect the highly age-affected characteristics of a student's development process. In addition, the impact of teachers will be limited and appears to be limited in that they are sensitive to stimuli in the surrounding environment. Therefore, schools should seek realistic guidance and alternatives in this area.

In conclusion, the core virtues of Personality education were chosen by this study. Currently, it is difficult to plan and implement in detail what and how to teach school personality education to have connectivity and differentiation for each school class. Therefore, it is necessary for teachers who think about and study personality education to introduce various key virtues in line with the development stage. While the core virtues of Personality education selected in this study are suitable for the development stage, they are thought to be used as basic data for the formation of personality values that can be experienced at each stage of development in orders to live in the future, focusing on the core virtues related to daily life. Based on the limitations of this study, I would like to propose a follow-up study. First, the core virtues of each stage of development were derived in this study, but studies on how to strengthen the derived virtues and how to evaluate the personality education after the personality education was conducted are insufficient. Therefore, further research is needed to foster the core virtues drawn up and strengthen Personality education. Second, since this study was conducted on incumbent teachers in Daegu and North Gyeongsang Province, there is a limit to generalizing the entire incumbent teachers, so more confirmation research is needed for incumbent teachers in all regions. 


\section{References}

[1] Park Eui-soo, A Historical and Epistemological Study of Korean Education Problems, The Education Problem Study, (2009), No.35, pp.43-62, UCI: G704-001272.2009..35.008

[2] Kim Soo-jin, Major access to personality education, Research on Curriculum, (2015), Vol.33, No.2, pp.207-229.

[3] Woo Young-Hyo, Character development in early childhood, The Korean Journal Child Education, (2004), Vol.13, No.1, pp.147-158.

[4] Lee Kyung-Min, Ideas for implementing pursuit of happiness education in early childhood education settings, Journal of Children's Media \& Education, (2009), Vol.8, No.1, pp.165-181. UCI : G704-001863.2009.8.1.003

[5] Jeong Jong-jin, Instructional Methods and Program Design Aimed at Promoting Self-esteem for Personality Development, The Korean Journal of Elementary Counseling, (2016), Vol.15, pp.537-561. UCI : G704-SER000003102.2016...006

[6] Kim Yu-ri, Kim Hyun-chul, Park Jin-ok, Kwon Sun-hyang, Kim Nuri, A New Paradigm of Character Education, Korean Education Inquiry, (2016), Vol.34, No.4, pp.1-20. DOI : 10.22327/kei.2016.34.4.001

[7] Choi Yong-sung, A study on the caring community in moral education, Journal of Moral \& Ethics Education, (2003), No.17, pp.85-102. UCI : G704-001279.2003..17.001

[8] Lee Yeon-soo, The Development of the Scale of Morality(SM) for Elementary School Students, Korean Journal of Elementary Education, (2016), Vol.27, No.2, pp.279-297. DOI : 10.20972/kjee.27.2.201606.279

[9] Kim Ha-nui, Son Eun-ryeong, Relationship among the Self-Esteem, Community Spirit, and School Adjustment of Adolescents: Focusing on the Mediating Effect of Multicultural Acceptability, The Journal of Learner-Centered Curriculum and Instruction (JLCCI), (2019), Vol.19, No.18, pp.361-381. DOI : 10.22251/jlcci.2019.19.18.361

[10] Min Ha-young, The Relationship with Self-Esteem, Parent-Related Stress and Coping in School Age Children, Korean Journal of Human Ecology, (2017), Vol.26, No.5, pp.383-392. DOI : 10.5934/kjhe.2017.26.5.383 